\title{
Dietrich of Freiberg's Theory of Perfectional Forms
}

\author{
Sylvain Roudaut \\ Stockholm University, Stockholm, Sweden \\ sylvain.roudaut@hotmail.com
}

\begin{abstract}
This article investigates the philosophical elaboration of the concept of "perfectional form" ( forma perfectionalis) in Dietrich of Freiberg's works. Although Dietrich draws on the traditional notion of perfection to a certain extent, it appears that in his view, what he calls perfectional forms represent a special type of form distinct from the classical division between substantial and accidental forms. The main part of the article analyzes the different uses of this concept made by Dietrich, from his theory of light to his views on the essence of the intellect. The final part of this study aims to evaluate the influence of Dietrich's theory on the so-called German Dominican school. It is argued that, while Dietrich's influence on Nicholas of Strasbourg is possible but cannot be firmly established, his theory was explicitly taken up and extended to a more metaphysical dimension by Berthold of Moosburg.
\end{abstract}

\section{Keywords}

form - perfection - hylomorphism - Dietrich of Freiberg - Nicholas of Strasbourg Berthold of Moosburg

\section{Introduction*}

At the end of the thirteenth century, Dietrich of Freiberg was one of the most original philosophers opposing the domineering influence of Thomas Aquinas in the Dominican Order. Following a trend typical of the so-called German Dominican school, Dietrich developed several themes inherited from Albert

* Many thanks to Evan King for his helpful comments on a previous version of this article. 
the Great's thought to build a complex metaphysics where Neoplatonist inspiration draws on an important redefinition of causality and types of causes. ${ }^{1}$ As is now well known, the concept of "essential cause", already extant in the writings of Dietrich's Dominican predecessors, ${ }^{2}$ is a crucial part of this redefinition. The theory of essential causation aims to describe an emanative causal process according to which a cause precontains the essence of its effect in a superior mode. It plays a central role in Dietrich's system and can be viewed as an attempt to reshape formal causation to better serve a Neoplatonist metaphysical framework. ${ }^{3}$ Nonetheless, Dietrich's most original contribution to the theory of formal causation may lie elsewhere. The distinction between substantial and accidental form is expected in an Aristotelian-based philosophy of nature. But, as several studies have shown, Dietrich analyzes this distinction in a particular way, granting to substantial forms a dynamic function in the composition of natural substances, and offering a rather deflationary account of accidents, which he regards as mere dispositions of material substances. ${ }^{4}$ However, Dietrich does not seem to find this classical distinction satisfying when it comes to the classification of forms and types of formal causality. In a refreshing ontological move, Dietrich introduces a sui generis type of forms, which he calls "perfectional forms", and presents it as distinct from both substantial and accidental form. As a few commentators have pointed out, this original concept comes up most often in physical discussions - more precisely in the De luce et eius origine - where its main function is to define light. ${ }^{5}$ But it also appears in metaphysical writings (in the De natura contrariorum) and in a theological question (Utrum in Deo sit aliqua vis cognitiva inferior intellectu). As evidenced by cross-referencing, the notion of "perfectional form" is an important concept

1 The bibliography on Dietrich of Freiberg is now quite extensive. For recent comprehensive studies, see Flasch, Dietrich von Freiberg; Kandler, Dietrich von Freiberg; Biard, Calma and Imbach, eds. Recherches; Kandler, Mojsisch and Stammkötter, eds. Dietrich von Freiberg.

2 See Albert the Great, Super Dionysium De divinis nominibus, 4, 262.

3 Dietrich uses essential causality to explain celestial motion, but he also relies on it to describe the relation of the agent intellect to the possible intellect and the soul. See Mojsisch, "Causa essentialis"; Mojsisch, "The Theory"; Sturlese, "Il De animatione caeli"; Decaix, "Structure"; Tsopurashvili, "Die causa essentialis-Theorie"; Suarez-Nani, Les anges, 142-164. On the history of this notion, see also De Libera, Métaphysique, 200-210; Erismann, “Causa essentialis"; Faës de Mottoni, "La distinzione"; Trego, "La métaphysique"; Rosemann, Omne agens, 187-220.

4 Dietrich of Freiberg, De accidentibus, $10,67^{88} ; 13,70^{66} ; 14,73^{4} ; 16,75 ; 17,77^{58} ; 21,83^{85-86} ; 22$, $85^{61}$; De quiditatibus entium $10,114^{52} ; 11,115^{16} ; 12,118^{40} ; 13,118^{13}$. On Dietrich's theory of accidents, see Maurer, "The De Quiditatibus Entium"; Imbach, "Metaphysik"; König-Pralong, "Le Traité"; McPike, Thomas Aquinas.

5 Flasch, Dietrich von Freiberg, 618, 623-626, 667; Wallace, The Scientific Methodology, ch. III, esp. 86, 91 ff.; Dijksterhuis, De mechanisering, ch. IV, 71. 
in Dietrich's writings. ${ }^{6}$ In his monograph on the Dominican philosopher, Kurt Flasch has emphasized its importance for Dietrich's conception of light, and rightly suggested that this notion had a large role to play, being part of Dietrich's renewed approach to the theory of the categories. ${ }^{7}$ Unfortunately, Flasch did not offer a thorough analysis of the conceptual relation between perfectional forms and the metaphysical principles used to define them. Nor did he conduct any comparative study of the various analyses of this concept in Dietrich's writings.

The aim of the present study is twofold. First, it intends to fill the aforementioned gap in the study of Dietrich's doctrine of perfectional form. To this end, the three following sections (2-4) study the notion of forma perfectionalis in the question Utrum in Deo sit aliqua vis cognitiva inferior intellectu, in the De luce et eius origine, and in the De natura contrariorum, respectively. This comparative inquiry will enable us to identify the characteristics and functions of perfectional forms in Dietrich's philosophical system. Second, the results of this inquiry will allow us to better determine how the concept may have influenced other Dominicans and, thus, to evaluate how it may have contributed to the metaphysical debates within the German Dominican school (section 5).

Perfections in the Question on God's Intellect

The term "perfection" has different meanings in late medieval scholasticism. According to the broadest acception of the term, a perfection is a property possessed by a subject, be it an essential property such as a capacity (as rationality can be said to be the highest perfection in human beings) or a fully actualized disposition (the habit of science, for instance, represents the perfection of a rational substance). By the end of the thirteenth century, however, the notion of perfection had acquired a more specific sense in psychological and anthropological discussions. A frequently-adopted definition was that the soul is the perfection of the body. Originating in the Latin translation of Avicenna's De anima, it provided a way to reconcile the substantial character of the human soul and its informative action on the human body. ${ }^{8}$ The term "perfection" implies that, considered in itself, the soul is an autonomous substance,

6 Dietrich of Freiberg, De natura contrariorum 40, $111^{22-23}$.

7 Flasch, Dietrich von Freiberg, 624-626, 667.

8 Avicenna [Avicenna latinus], Liber de anima, I, 1, 20. On the definition of the human soul as perfection and related controversies in the thirteenth century, see Lenzi, Anima, and De Boer, The Science, esp. 18-25. 
while, when considered in relation with the matter it informs, it is the form of the body. Among many other theologians, Albert the Great - arguably the most important influence on Dietrich's thought - adopted this definition of the soul. ${ }^{9}$

As we will see, the expression "perfectional forms" - as it is used by Dietrich in different writings - is not unrelated to the usual meaning of perfection. However, Dietrich gives a precise and original definition of these entities since he holds them to be a special type of form. He first developed the notion of perfectional form in a question devoted to the nature of divine cognition, Utrum in Deo sit aliqua vis cognitiva inferior intellectu. ${ }^{10}$ Written around 1297 , the question focuses mainly on theological issues but it also contains reflections on the general properties of intellection. After concluding that there can be no cognitive faculty inferior to the intellect in God, Dietrich explains that such an inferior faculty is, however, necessary for intellects that do not always understand and, therefore, go from potency to act. Those intellects which cannot go from potency to act by themselves require another element to become fully in act. ${ }^{11}$ According to Dietrich, this inferior cognitive element is provided by the phantasma. In his justification for this point, Dietrich must explain how a possible intellect that is united to the agent intellect can be always disposed to receive an intelligible form without always understanding in act. ${ }^{12}$ It is to solve this problem that Dietrich first makes use of "perfectional forms" in this early theological question, being led to this solution by a study of the different possible relations between form and disposition. Indeed, Dietrich shows that one can use the relations between the ultimate disposition of a substance and the reception of form in it in order to distinguish different kinds of forms. This means that distinct modal relations between forms and their actualization lead to distinctions between various types of forms. More precisely, the resulting distinction between ways of being in potency (or being disposed to a form) is threefold. First, some forms are such that when a subject is adequately disposed to receive them, it cannot but receive them. In other words, some forms are such that the ultimate disposition of a subject toward them necessarily leads to their reception. This is the case for substantial forms, which a subject necessarily receives as soon as it is ultimately disposed toward it:

\footnotetext{
9 See Park, "Albert's Influence," and Hasse, "The Early Albertus Magnus."

10 See Flasch, Dietrich von Freiberg, 625-626, 667.

11 Dietrich of Freiberg, Utrum in Deo, 1, 4, 296-302.

12 Dietrich of Freiberg, Utrum in Deo, 2, 2, 1, 308.
} 
From what has been said, it is clear that in the generation or institution of substances the ultimate disposition toward form is the same disposition that is the necessity by which the material subject - being itself a being in potency - does not reject form and is necessarily joined with it. ${ }^{13}$

Dietrich insists on the fact that such a disposition requires two conditions - a point allowing him to differentiate the mode of reception proper to substantial forms from the mode of reception of accidents. On the one hand, such a disposition of the subject requires an external agent (the generator) acting on the matter which receives a new substantial determination. ${ }^{14}$ Thus, it can be said that this agent essentially causes the ultimate disposition of the subject receiving a new substantial determination. ${ }^{15}$ On the other hand, the matter which receives this new determination needs to be internally actualized. Consequently, the process leading a subject to its ultimate disposition also requires the new substantial form to inform the matter. ${ }^{16}$ In this process, the agent causing the ultimate disposition of a subject is the efficient cause of the substantial change, while the informing principle acts as the formal cause in this process. ${ }^{17}$

Whereas this first type of disposition toward forms implies a necessary relation between the disposed subject and the form received, a second type of disposition signals a stronger relation between them. This second type concerns the ultimate disposition toward qualitative accidents (e.g., hotness and coldness). For this type of form, not only does the ultimate disposition of the subject necessarily lead to the reception of the form - it is, strictly speaking, the form itself. The relation of identity between the ultimate disposition of the subject and the form itself concerning qualitative properties follows directly from Dietrich's definition of accidents as dispositions of material substances:

The subject's ultimate disposition toward accidental forms, such as hot, cold and similar ones, is different in substances. In these, indeed, there is

13 Dietrich of Freiberg, Utrum in Deo, 2, 2, 3, 312 48-51: "Secundum haec igitur, quae dicta sunt, manifestum est, quod in generatione seu institutione substantiarum ultima dispositio ad formam est ea dispositio, quae est necessitas, secundum quam subiecta materia, quae est ens potentia, non abicit formam, sed necessarie sunt simul."

14 Dietrich of Freiberg, Utrum in Deo, 2, 2, 3, 31111-19.

15 Dietrich of Freiberg, Utrum in Deo, 2, 2, 3, 3118-19: "Et sic ultima dispositio subiectae materiae est ab agente essentialiter."

16 Dietrich of Freiberg, Utrum in Deo, 2, 2, 3, 31120-21: "Ab alio autem principio simul concurrente est ultima dispositio materiae subiectae ad formam; quod principium est forma rei generatae ..."

17 Dietrich of Freiberg, Utrum in Deo, 2, 2, 3, 312 $37-47$. 
no distinction between the subject's ultimate disposition, the substance, and such an accidental form according to their being (secundum rationem essendi), that is to say while the subject is actually informed by this form, but the form itself is the ultimate disposition of the subject. ${ }^{18}$

These first two modes of form reception have a common feature: in both cases, the existence of the new form requires an external agent (the generator), and formal reception necessarily follows from the ultimate disposition of the subject. But they differ, since, in the second case (i.e., qualitative accidents), a strict identity relation between the disposition and the form itself exists, because, according to Dietrich, accidents have no ontological autonomy and are entirely dependent on their subject. ${ }^{19}$

Things are different for perfections, which constitute the third way in which a subject can receive a form. In this case, the ultimate disposition of the subject does not necessarily imply the reception of the form. Rather than a relation of necessity between a form and the ultimate disposition of a subject, as in the two previous cases, perfections imply a contingent relation between a subject and its actualization. For instance, the subject can be fully in act, but still lack the ontological complement which only an external agent can provide:

Third, a subject can be in its ultimate disposition toward some form of another genus, different from the forms that have just been described. The forms of which we speak now, indeed, are such that a subject acting in substantial or accidental act is not sufficient to cause such a form in act, but necessarily requires some extrinsic principle operating according to a certain mode of principle (modus principiandi) for these forms to be in a subject. For instance, when light is received in some thing and this thing becomes luminous in act, like luminous air or water, the agent that makes water or air to be in the act of substance or of their other qualities does not suffice, but the presence of a luminous body is necessarily required. ${ }^{20}$

18 Dietrich of Freiberg, Utrum in Deo, 2, 2, 3, 312 $2^{52-57}$ : "Alio autem modo, quod in substantiis attenditur ultima dispositio subiecti ad formas accidentales, puta calidum, frigidum et similia. In huiusmodi enim non est distinguere inter ultimam dispositionem subiecti et substantiam et ipsam formam talem accidentalem secundum rationem essendi, id est dum subiectum actu informatur tali forma, sed ipsa est ultima dispositio subiecti."

19 Dietrich of Freiberg, Utrum in Deo, 2, 2, 3, 312 $32-68$.

20 Dietrich of Freiberg, Utrum in Deo, 2, 2, 3, 313 $399-78$ : "Tertio modo attenditur ultima dispositio subiecti ad aliquam formam alterius generis quam sint istae, de quibus immediate dictum est. Sunt enim huiusmodi formae, de quibus nunc agitur, talis maneriei, quod agens subiectum in actum substantialem vel accidentalem non sufficit ad causandum 
In this third mode of being in potency regarding form, the form completes the subject's actuality, and for this reason it can be called perfectio, following the literal meaning of the term. This first definition of "perfection" is, of course, motivated by the requirements of Dietrich's theological concerns and by his analysis of cognitive processes. But we must note that Dietrich already relies on the analogy of light in this context.

Indeed, this last type of form enables Dietrich to explain the status of the possible intellect. The possible intellect is in a way analogous to a luminous body in the physical realm and analogous to the senses on a psychological level. For, just like the actualization of light requires an external agent, and just like the act of sensation requires an external object, the possible intellect needs an intelligible object in order to be actualized. However, the possible intellect does not need an entirely external object in order to understand: its objects are given to it by the activity of the agent intellect, which always thinks objects through its own essence. ${ }^{21}$ Nonetheless, created possible intellects are also always ultimately disposed toward intelligible forms and are at the same time in potency regarding these forms:

From what has been said, it is clear that for the genus of form in question, every such form is in potency in its own proper subject and in the ultimate disposition toward its complete act. But since they can only exist in their complete ultimate actuality owing to some extrinsic principle, which is not always present, it follows that in this case the ultimate disposition is not this necessity by which such forms inhere necessarily in act. ${ }^{22}$

Even though Dietrich does not explicitly place the possible intellect among perfectional forms, the speculative and practical habits of the intellect do belong to this class of forms:

talem formam in actu, sed necessario requiritur aliquod extrinsecum principium secundum quemcumque modum principiandi hoc, scilicet ut tales formae sint in subiecto; puta, quod lumen recipiatur in aliquo et fiat actu lucidum, ut aqua vel aer lucidus, non sufficit agens aquam vel aerem in actum suae substantiae seu aliarum qualitatum suarum, sed necessario requiritur praesentia corporis luminosi."

21 Dietrich of Freiberg, Utrum in Deo, 1, 4, 2, 300-12. See also De visione beatifica, 1, 1, 1, 3, 1, 28 ${ }^{70-77}$; De intellectu et intelligibili III, 25, 199 ${ }^{129-140}$.

22 Dietrich of Freiberg, Utrum in Deo, 2, 2, 3, 314 115-121: "Secundum ea igitur, quae dicta sunt, manifestum est, quod quantum ad huiusmodi genus formarum, de quo nunc agitur, quaelibet earum est in potentia in subiecto suo proprio et in ultima dispositione ad actum suum completum; sed quia ad existendum in ultimo suo actu completo dependent ab aliquo exteriore principio, quod non semper praesens est, ex hoc ultima huiusmodi dispositio non est ea necessitas, qua necessario insint tales formae in actu." 
Speculative and practical habits belong to this mode of existence in potency, which explains that what possesses them is sometimes in accidental potency toward a complete act, namely when it does not actually operate according to those habits. ${ }^{23}$

Because rational habits belong to the third class of forms, they appear similar to sensitive activities - a point confirmed in the De natura contrariorum, where Dietrich will define the first species of qualities (science, health, virtues, etc.) as perfections. In the question Utrum in Deo, perfectional forms allow Dietrich to explain the mechanism of intellection in created beings. The created intellect is what Dietrich calls an ens conceptionale, i.e., a being ontologically constituted by its self-reflective activity. ${ }^{24}$ Although the possible intellect of created beings is always adequately disposed toward the reception of intelligible forms, it does not always understand due to its particular mode of potency. ${ }^{25}$ By contrast, the agent intellect is pure actuality (even in created beings). The use of perfectional form allows Dietrich to explain how such a created intellect - despite being an ens conceptionale - still depends on external principles for its cognitive activities. In fact, the human possible intellect requires sensitive activity - whence the contingent character of intellectual habits which, as perfectional forms, must be actualized by an inferior cognitive element (phantasma). Perfectio gives a created essence the possibility to reach its final end through adequate actualization. Essence and operation are only identical in an intellect per essentiam, which is always pure actuality. But for those beings whose essence is not immediately identical to their operation, like human beings, further actualization is needed to achieve their final end through perfection. As our analysis has just shown, the question on God's intellect points to matters beyond the theological issues it is directly concerned with: it can shed light on the profound reasons underlying Dietrich's frequent identification of operation and perfection. ${ }^{26}$

23 Dietrich of Freiberg, Utrum in Deo, 2, 2, 3, 314 125-128: "Ad istum etiam modum existendi in potentia reducuntur habitus speculativi et practici, secundum quos habens eos est quandoque in potentia accidentali ad actum completum, quando videlicet non actu operatur secundum tales habitus."

24 On this notion, see Mojsisch, "Sein als Bewußt-Sein," and Mojsisch, "Die Theorie des Bewußtseins."

25 Dietrich of Freiberg, Utrum in Deo, 2, 2, 3, 314 $4^{140}-315^{145}$; De visione beatifica, 1, 2, 2, 1, $46^{16-}$ 17; De intellectu et intelligibili III, 2, 179. The possible intellect needs an intelligible form to be in act (De intellectu et intelligibili II, 2, 147 ${ }^{58-59}$ ) even though the intelligible form is not an accidental form strictly speaking, i.e., not a material disposition affecting the intellect (De intellectu et intelligibili III, 6, 181-182; III, 13, 186-187).

26 Dietrich of Freiberg, De visione beatifica, 2, 3, 67 $7^{48-49}$ : "Sicut autem unaquaeque res est 
The next development in Dietrich's theory of perfectional forms appears in the De luce et eius origine, written in $1304 .{ }^{27}$ In this treatise, Dietrich relies on an analogy between light and the senses to explain the nature of light, which he describes as a "perfectional form". ${ }^{28}$ However, Dietrich's account of perfectional form in the De luce is markedly different from his earlier account in the question Utrum in Deo.

Dietrich's purpose being to identify the causes of light, his inquiry in the $D e$ luce begins with a distinction between three types of efficient or agent causes. ${ }^{29}$ In a first sense, an efficient cause refers to an entirely separate agent, which can produce an object immediately and instantaneously, like God and the Intelligences postulated by the philosophers do. Another type of agent cause requires motion to produce an effect. This type of cause belongs to celestial bodies and to some natural substances which possess a principle of motion within themselves. ${ }^{30}$ The third type of agents - like the elements and their active qualities are causes that act on behalf of these superior causes, as their instruments in the sensible world. ${ }^{31}$

Since the De luce aims to determine the essential cause of light as a physical phenomenon, the efficient cause in the first sense (God's action) is excluded. ${ }^{32}$ But focusing on the natural causes of light requires a distinction between essential and accidental causes, for the action of an essential cause does not preclude the presence of accidental causes. Yet, the concept of accidental cause remains ambiguous, having two distinct meanings. This distinction is best interpreted through an analogy with sense perception, which also implies a kind of double causality (essential and accidental):

propter suam operationem, quae est eius perfectio ..." See also $3,2,4,74^{21}$; De intellectu et intelligibili I, 1, 137 ${ }^{3-4}$; De accidentibus, 8, $64^{107-109}$.

27 See Flasch, Dietrich von Freiberg, 623-625.

28 Dietrich of Freiberg, De luce, $7,15^{28-30}$ : "Ceterum de lumine, quod est propria forma diaphani secundum Philosophum, cuius generatio multum assimilatur generationi sensuum, agendum"; De luce, 19, $23^{99}-24^{101}$ : "Quantum autem ad exitum de potentia accidentali quoad actum aliquem, qui est forma perfectionalis, non attenditur generatio et corruptio substantiae rei, sed tantum perfectio. Et talis forma est lumen ...”

Dietrich of Freiberg, De luce, 2, 9-10. See also De visione beatifica, 3, 2, 9, 5, 93-96; De animatione caeli, 6-9, 17-20.

30 Dietrich of Freiberg, De luce, 2, 10 $39-43$.

31 Dietrich of Freiberg, De luce, 2, 10 14-52.

32 Dietrich of Freiberg, De luce, $3,1^{60}-11^{66}$. 
But accidental potency is twofold, for it can happen in two ways that an accidental potency lacks its effect or the act toward which it tends: first because of some obstacle (impedimentum), i.e., because it is impeded in its natural disposition, like a heavy body when it is detained above by force; in another way because of the absence of a thing whose presence is required per se for such a potency to proceed to such an act, like the power of vision, because of the absence of a visible thing whose presence is required per se for the act of seeing, is in accidental potency in another sense than the first one. Things that are in accidental potency in this way have in their nature a natural and per se relation to the thing whose presence is required per se for them to be in act, like Augustine says in $\mathrm{On}$ Genesis, that necessarily things had to exist prior to the angels' evening knowledge. And in On the Trinity XII, chapter 5, Augustine also says that, when something new appears in creatures, from this the corporeal senses of animals and the spiritual ones of angels are moved. According to this mode of accidentality the senses are moved toward their act by accident, that is to say by the person who brings the sensible close to the sense, just like in the other mode of accidentality the person who removes the obstacle moves by accident the heavy or light elements. ${ }^{33}$

The case of the senses serves a precise function in Dietrich's argumentation: it shows that some entities require both essential and accidental causes to be thoroughly explained. Such a double causality arises from the fact that some entities depend on external things for their existence. In other words, it is not an accidental feature of the senses that they depend on an external thing - rather,

33 Dietrich of Freiberg, De luce, 4, $11^{83}-12^{99}$ : "Sed potentia accidentalis duplex est, quia dupliciter potest contingere, ut careat effectu suo, ne videlicet sit in actu, ad quem est: uno modo propter impedimentum, quia videlicet impeditur in sua naturali dispositione, ut grave, si violenter detineatur sursum; alio modo propter absentiam alicuius rei, cuius praesentia per se requiritur ad hoc, quod talis potentia exeat in actum talem, ut potentia visiva propter absentiam visibilis, cuius praesentia per se requiritur ad actum videndi, est in potentia accidentali alio modo a praedicto. Huiusmodi enim, quae sic sunt in potentia accidentali, habent in sui natura naturalem et per se respectum ad id, cuius praesentia per se requiritur ad hoc, quod talia sint in actu, sicut Augustinus dicit Super Genesim, quod oportuit necessario praeexistere res ad cognitionem angelorum vespertinam. Et XII De Trinitate c. 5 dicit etiam Augustinus, quod, quando aliquid novum oritur in creatura, ex hoc moventur sensus et corporales animalium et spirituales angelorum. Secundum istum modum accidentalitatis moventur sensus ad actum suum per accidens, scilicet per illum, qui adhibet sensibile sensui, sicut in alio modo accidentalitatis ille, qui removet prohibens, movet per accidens elementa gravia vel levia." 
it is part of their definition as senses. ${ }^{34}$ In this case, the essential cause is the agent generating a subject capable of sensations, while the perceived object acts as an accidental cause on the sensitive power of the subject:

From the generator come the foundations of such relations as well as this relation itself by which the sense is in accidental potency toward the act of sensation caused by the proximity of a sensible object, like in another genus of accidentality this form of heaviness and the downward inclination in heavy things come from the generator and become actual by what removes the obstacle. And this is what the philosopher says in On the Soul II, that the first alteration of what is capable of sense perception comes from the generator. The sense does not come to be in act by the action of a sensible upon it, since the sensible is a body and no physical body acts instantaneously, as will appear later. ${ }^{35}$

The case of light (lumen) in a given medium is similar, since the lumen also implies a per se relation to some external agent, namely the source of light. For instance, if the transparency of a given medium is a necessary condition for the reception of light, then the essential cause of an illuminated medium is the cause of its transparent form (forma diaphani). But, as we said above, the essential cause of light in a medium does not preclude the action of some accidental cause: considered in itself, i.e., as a possible property of a medium appearing in precise circumstances, the lumen is a type of accident. ${ }^{36}$ But how can an accident be ontologically dependent on an agent different from the subject in which it inheres? This complex issue is the reason why Dietrich's def-

34 Dietrich of Freiberg, De luce, 5, 12 ${ }^{7-14}$ : "Unde completa generatione animalis secundum substantiam ipsum est in ultima dispositione, quod habeat sensum in actu, et est in potentia accidentali propter absentiam sensibilis, ad quod secundum actum suum sensus habet per se respectum, sine quo nec esset sensus secundum actum nec operatio sensitiva, quod idem est, et propter talem respectum, qui naturaliter et per se adhaeret sensui in actu, fit sensus per se in actu in instanti et non successive nec per motum, quia non est motus in respectum secundum Philosophum in v Physicorum."

35 Dietrich of Freiberg, De luce, 5, 12 ${ }^{15-22:}$ : Fundamenta autem talium respectuum fiunt a generante et etiam ipse respectus, quo est in potentia accidentali ad actum sentiendi in adhibitione sensibilis, sicut in alio genere accidentalitatis ipsa forma gravitatis et inclinatio deorsum in gravi est a generante et fit in actu per removens prohibens. Et hoc est, quod dicit Philosophus in II De anima, quod prima alteratio sensitivi est a generante. Nec fit sensus in actu per aliquam actionem sensibilis in sensum, quoniam sensibile est corpus et nullum corpus physicum agit in instanti, ut postea patebit."

$3^{6}$ Dietrich of Freiberg, De luce, 8, 1644-45: "Est igitur lumen qualitas seu forma quaedam realis in diaphano, sed forma accidentalis." 
inition of perfectional form in the De luce stands out when compared with the definition found in his other writings. In the latter, Dietrich classifies forms on the basis of their metaphysical properties. But in the De luce, he defines perfections from a physical standpoint, relying on the concept of "physical parts". For, like other accidents, perfections are dispositions of material substances, and dispositions imply having what Dietrich calls partes post totum, i.e., physical parts that characterize individual natural substances:

Every accidental form, however, is nothing else than a certain disposition. But a disposition belongs to a thing having parts, according to the Philosopher in Metaphysics v, and insofar as it has parts, not just any kind of parts, but parts that are posterior to the whole, which account for the fact that something is an individual - something we can deduce from Metaphysics VII where it is said that the semicircle is not a part of the circle, but of this circle, and that the acute angle is not part of the right angle, but of this right angle. ${ }^{37}$

Thus, all accidents, conceived as dispositions of substances, depend on the organization of physical parts. However, since perfections are a special kind of accidents - having a per se relation to some external agent - Dietrich has to show that parts can be of different kinds. He begins his typology of parts by dividing them into two broad classes:

1. Absolute parts that do not require the presence of another thing in order to exist. ${ }^{38}$

2. Relative parts whose existence requires the existence of another thing. ${ }^{39}$ Sensations and light are examples of the second type:

37 Dietrich of Freiberg, De luce, 8, 16 $6^{45-51: ~ " O m n i s ~ a u t e m ~ f o r m a ~ a c c i d e n t a l i s ~ n a t u r a l i s ~ n o n ~ e s t ~}$ nisi dispositio quaedam. Dispositio autem est habentis partes secundum Philosophum in $\mathrm{v}$ Metaphysicae, et inquantum habet partes, non quascumque, sed eas, quae sunt post totum, in quo consistit ratio, quod aliquid est individuum, sicut habemus ex vir Metaphysicae, ubi dicitur, quod semicirculus non est pars circuli, sed huius circuli et quod acutus angulus non est pars recti anguli, sed huius recti." See also De visione beatifica, 2, 3, 4, 76 $6^{79-}$ 81; De intellectu et intelligibili $\mathrm{II}, 18,158^{72-73}$.

38 Dietrich of Freiberg, De luce, 9, 16 $6^{56-59}$ : "Hoc potest esse dupliciter: uno modo, ut ex talibus partibus constet individuum secundum absolutam sui existentiam ita, quod non sit necessaria alicuius alterius rei praesentia ad hoc, quod tale individuum constet ex talibus partibus in actu."

39 Dietrich of Freiberg, De luce, 9, 16 63-65: "Alio modo contingit rem constare ex partibus non secundum absolutam existentiam eo, quod secundum existentiam talium partium requiritur existentia alicuius alterius rei, in cuius respectu constat res ex talibus partibus." 
And because of this, the form which is the disposition of the thing having such parts is not an absolute form, but rather a relative one, like sensitive forms that actualize the sense, as can be deduced from what was said earlier. And such are the parts of the transparent insofar as it is transparent. And the form which is the disposition of the transparent having these parts is light, whose existence necessarily requires the presence of a luminous body. ${ }^{40}$

These two classes of parts can be specified further if one examines specifically the parts present in natural individual substances. Natural substances are generated by some motion, differently from incorruptible beings, which proceed directly from higher separate entities without being naturally generated. The first general class of parts (absolute parts) can then be divided into two subgroups. The first type of parts in natural substances comprises substantial properties. Being necessary for the existence of natural substances, these parts have two characteristics: being caused by a generator and being invariable. ${ }^{41}$ They are substantial forms, and Dietrich claims that unlike quantitative or qualitative parts, they determine the identity of a subject over time. They remain numerically the same through accidental changes and can be called the first and principal parts of substances since they are absolutely necessary for their existence:

Some parts, indeed, are the first, main, and necessary parts for the subsistence of an individual, without which such an individual would not exist. And they are invariable in its substance, so that they cannot be disposed differently as long as this substance persists. And thus the form, which is the disposition of such a substance according to its parts, is invariable for this substance. ${ }^{42}$

40 Dietrich of Freiberg, De luce, 9, 16 $6^{65}-17^{71}$ : "Et secundum hoc forma, quae est dispositio rei secundum tales partes, non est omnino absoluta forma, sed magis respectiva, ut formae sensitivae facientes sensus in actu, ut ex praemissis habetur. Et tales partes sunt partes diaphani inquantum diaphanum. Et forma, quae est dispositio diaphani secundum has partes, est lumen, quod ad sui existentiam necessario requirit praesentiam corporis luminosi."

41 Dietrich of Freiberg, De luce, 11, $18^{15-23}$.

42 Dietrich of Freiberg, De luce, 11, 18 11-15: "Quaedam enim sunt partes primae et principales et necessariae ad subsistentiam individui, sine quibus tale individuum non existeret, et sunt invariabiles in substantia sua ita, quod aliter disponi non possunt manente ipsa tali substantia, et per consequens forma, quae est dispositio talis substantiae secundum suas partes, invariabilis est circa talem substantiam." 
The second type of parts consists of accidents. As absolute parts of natural substances, they are caused by the generation of the subject, but unlike the first type they are subject to alteration and will vary over time (e.g., from hotness to coldness, from whiteness to blackness, and so on). Although this second type of parts can vary due to the external influences of other bodies, Dietrich does confirm that it belongs to the general class of absolute parts like the first type of dispositions:

And according to these two genera of parts and forms an individual subsists absolutely by itself without having the need of some other thing's presence in order to actually remain under the disposition of these parts. ${ }^{43}$

Finally, parts of the third kind are called perfectional parts or perfectional forms. In addition to a generator, they require an external thing to be in act:

According to parts of this kind, a thing comes to be in act due to the presence of some other thing, which is per se required, like the presence of sensible beings is required for a thing to be actualized according to its sensible forms, like being seen, being heard, and so on. ${ }^{44}$

Several properties of perfectional forms will be covered more thoroughly in the De natura contrariorum. Yet Dietrich anticipates on this account in the De luce, mentioning that perfectional forms do not have contraries, and that the subject is in accidental potency toward them. ${ }^{45}$ Likewise, he does not dwell on the metaphysical status of these forms in the 1304 De luce (metaphysical analyses will be conducted in more detail in the De natura contrariorum) but his justification of the use of the adjective "perfectional" fits perfectly with the later, more detailed account:

These parts and forms ... can be conveniently and properly called perfectional parts and forms since a thing, according to these parts and forms

43 Dietrich of Freiberg, De luce, 12, 1944-46: "Et secundum ista duo genera partium et formarum subsistit individuum absolute secundum se non indigens praesentia alicuius alterius rei ad hoc, quod actu stet sub dispositione talium partium."

44 Dietrich of Freiberg, De luce, 13, 19 tiam alicuius alterius, quod per se requiritur, ut praesentia sensibilium requiritur ad hoc, quod res fiat in actu secundum suas formas sensibiles, puta visum, auditum et cetera." 
(secundum eas), is as it were in its ultimate perfection, which its nature cannot reach without the presence of some extrinsic thing. ${ }^{46}$

The distinction of those three types of parts finally allows Dietrich to elucidate the causes of light (lumen). On the one hand, the generator of the transparent medium is its essential cause, and, on the other hand, the external source of light (operating as an accidental cause) actualizes the perfectional parts of the medium:

So if it is asked what the efficient cause of light in the transparent is, it must be said that what generates the substance of the transparent simultaneously educes from essential potency the perfectional parts and the form that is the disposition of the transparent according to these parts, this form being light (lumen). Toward this form the transparent is in accidental potency until some luminous body is present. And in this way what first alters the transparent to the form of light is the generator educing this form from essential potency; but due to the presence of a luminous body this form proceeds from accidental potency to the ultimate complete act of light. And this mode of parts and forms as well as this way of going from potency to act belong to the third class of parts and forms just described, as is clear, which I called perfectional forms and parts. ${ }^{47}$

Perfectional forms are introduced in the De luce as a conceptual resource to justify Dietrich's view on the causes of light. At first glance, this definition of light as a "perfection" does not seem particularly new. Commenting on Aristotle's definition of light, Avicenna had famously distinguished between lumen and lux , and defined lux as a perfectio translucentis. ${ }^{48}$ Albert the Great, discussing

46 Dietrich of Freiberg, De luce, 13, 20 ${ }^{78-81}$ : "Possunt autem istae partes et formae ... convenienti et proprio nomine dici partes et formae perfectionales eo, quod res secundum eas est quasi in ultima sua perfectione, ad quam non potest pertingere natura sua sine praesentia alicuius extrinseci."

47 Dietrich of Freiberg, De luce, 14, 2091-101: "Si igitur quaeratur, quae sit causa efficiens luminis in diaphano, dicendum, quod generans ipsam substantiam diaphani educit simul de potentia essentiali partes perfectionales et formam, quae est dispositio diaphani secundum illas partes, quae forma est lumen, ad quam formam stat ipsum diaphanum in potentia accidentali usque ad praesentiam alicuius luminosi. Et sic primum alterans diaphanum ad formam luminis est generans educens ipsam de potentia essentiali, sed ad praesentiam luminosi exit de potentia accidentali ad actum luminis ultimum completum. Et pertinet iste modus partium et formarum et exitus de potentia in actum ad tertium genus partium et formarum immediate praemissum, ut patet, quas dixi formas et partes perfectionales." Aristotle, De anima II, 7, 418b10; Avicenna [Avicenna latinus], Liber de anima III, 3, 194. 
Avicenna's doctrine, had also accepted this account of light as the perfection of a medium. ${ }^{49}$ But the importance of Dietrich's contribution on the nature of light does not lie in its novelty. It is rather his singular usage of perfectional form that marks him out. For the way Dietrich defines light as a perfection allows him to take a stance on a controversial issue of his day while consolidating his own system. Indeed, one of the most hotly debated issues about light in Dietrich's time concerned its ontological status. ${ }^{50}$ Is light a substantial or an accidental entity? On the one hand, there seems to be some evidence that light is an accident, because it always exists within a medium. On the other hand, light has no proper contrary, which appears to be a decisive argument to call it a substance (given that substances do not have contraries, according to a famous Aristotelian principle ${ }^{51}$ ). Defining light as a perfectional form allows Dietrich to propose an elegant solution which accommodates both sides: it fits with the consensual claim that light has no real contrary, but at the same time it explains how light can only exist as an accident in a subject. ${ }^{52}$

But the role of perfection in the De luce is not solely to solve the problem of the causes of light. Dealing with a dubium about the nature of the sky, Dietrich also uses it to justify how light can be present in it, even though the sky is an incorruptible being which cannot receive accidents. It is precisely due to the particular status of perfections that the sky, although it is incorruptible and devoid of potentiality, is nevertheless in potency toward light. As an incorruptible being, the sky cannot be a subject of inherence for accidents. Yet its ontological status allows it to receive perfections, since perfections are not purely accidental determinations, but rather ontological complements supervening on actual beings. This possibility to receive perfections in actu is due to a certain kind of potency, namely accidental potency (potentia accidentalis):

But to this [dubium] it must be said that a thing is said to be generable and corruptible insofar as it proceeds from essential potency to the act toward which the motion of generation and corruption tends. And in this way we can understand that the heaven does not receive alien impressions (peregrinas impressiones), that is to say insofar as it proceeds from essential potency. But insofar as it proceeds from accidental potency with respect to some act which is a perfectional form, the generation and cor-

49 Albert the Great, De homine, $153^{-162 .}$

50 On the medieval debates over the nature of light stemming from the divergent interpretations of Aristotle's doctrine, see Vasiliu, Du diaphane.

$5^{1} \quad$ Aristotle, Categories, 5, 3b24-27.

$5^{2}$ See Flasch, Dietrich von Freiberg, 623. 
ruption of a thing's substance is not concerned, but only its perfection. And light (lumen) is such a form - either in celestial bodies or in inferior ones - toward which the heaven can be in accidental potency, just as we see in substances higher than the heaven, for example in separate substances or spirits, which are in accidental potency toward their perfectional forms, as Augustine says in On the Trinity XII, that when something new appears in creatures, the corporeal senses of animals and the spiritual ones of angels are affected anew. ${ }^{53}$

Considering Dietrich's position on the emanative structure of the universe, this point is of the utmost importance. The sky acts as a bridge between the higher spheres of being and the natural world, for celestial light carries the most active qualities (hotness and coldness) responsible for changes into the sublunar realm. Natural substances, since they are individuals composed of partes post totum, i.e., material parts, can only be generated and corrupted through this celestial mediation. ${ }^{54}$ Light in itself does not possess active qualities, but is only the vehicle (vehiculum) of such properties:

The same is clear with respect to luminosity (de lumine), which is something real coming from the effects of light (luminis). It is indeed a sort of vehicle of the celestial power (virtus) that presides over the region of generable and corruptible things by means of heat coming from the stars, as the Philosopher says in On the Heavens II. $^{55}$

53 Dietrich of Freiberg, De luce, 19, $23^{95}-24^{107}$ : "Sed dicendum ad hoc, quod generabile et corruptibile dicitur aliquid secundum exitum de potentia essentiali ad actum, ad quem tendit motus generationis vel corruptionis, et sic etiam intelligitur, quod caelum non recipit peregrinas impressiones, scilicet secundum exitum de potentia essentiali. Quantum autem ad exitum de potentia accidentali quoad actum aliquem, qui est forma perfectionalis, non attenditur generatio et corruptio substantiae rei, sed tantum perfectio. Et talis forma est lumen - sive in corporibus caelestibus sive in istis inferioribus, ad quod non est impossibile caelum esse in potentia accidentali, sicut etiam videmus in substantiis altioribus caelo, puta in substantiis separatis seu spiritibus, quod sunt in potentia accidentali ad suas formas perfectionales, sicut dicit Augustinus XII De Trinitate, quod, quando aliquid novi oritur in creatura, ex hoc de novo afficiuntur sensus corporales animalium et spirituales angelorum."

54 Dietrich of Freiberg, De luce, 10, 17 ${ }^{83-88}$ : "Et talia sunt incorruptibilia secundum naturam, tum quia talia principia non habent contrarium in agendo, tum quia essentia inquantum essentia non habet contrarium ... Oportet autem viam corruptionis incipere ab eo, unde incipit via institutionis in esse; via autem institutionis in esse incipit ab essentia inquantum huiusmodi in istis ingenerabilibus et incorruptibilibus."

Dietrich of Freiberg, De luce, 8, 16 $6^{39-42}$ : "Patet etiam idem de lumine, quod est quid 
In the De luce, Dietrich gives a physical account of perfectional forms, as evidenced by the equivalent expressions "perfectional forms" and "perfectional parts". Furthermore, the ontological distinction of three general form types enables him to account for the special nature of light while simultaneously justifying some of his cosmological claims.

\section{Perfectional Forms in the De natura contrariorum}

The most detailed analysis of perfectional forms is found in the Tractatus de natura contrariorum. As per the title, the treatise investigates contraries, but it also contains significant developments on other topics, such as the nature of forms. ${ }^{56}$ Although the analysis of formae perfectionales does not constitute the core of the De natura contrariorum, the description of these particular entities makes for a meaningful passage in this work. Perfectional form is introduced in paragraph 36 , preceeding the thorough analysis of forms which constitutes the second half of the treatise. In this paragraph, while conceding that perfectional forms belong in a certain sense to the class of accidents, Dietrich once again signals how they differ from both substantial and (other) accidental forms:

Other forms, however ... are not of this kind. For from them and a subject a being does not arise in the way that has been described, but they are rather perfections of some being. Indeed, such perfections presuppose a being constituted as described both according to substantial being and according to accidental being. ${ }^{57}$

Later, in paragraph 58 , Dietrich cites Aristotle's Physics to emphasize that qualities of the first species (habits such as virtues and vices) are not true qualities, but should rather be called perfections (quaedam entium perfectiones). ${ }^{58}$ The

reale ex effectibus luminis. Est enim quoddam vehiculum virtutis caelestis praesidentis regioni generabilium et corruptibilium mediante calore, qui descendit ex stellis secundum Philosophum in II De caelo et mundo."

56 See Roudaut, "The Definition," esp. 40-42 on perfections.

57 Dietrich of Freiberg, De natura contrariorum, 36, 108 $8^{24-27}$ : "Aliae autem formae ... non sunt talis modi. Non enim ex ipsis et subiecto fit aliquod ens modo praedicto, sed potius sunt alicuius entis perfectiones. Supponunt enim huiusmodi perfectiones ens praedicto modo constitutum et secundum esse substantiale et secundum esse accidentale."

58 Dietrich of Freiberg, De natura contrariorum, $58,125^{79-80}$. Cf. Aristotle, Physics vil, 3, 246a1o-b3, 246b2o-247a3. Aristotle also defines the notion of habit in the Categories (8, 
reference to Aristotle is worth noting, since it provides a good illustration of Dietrich's general strategy in the De natura contrariorum when it comes to the status of perfections: while he clearly grants a special status to these forms, he also needs his theory to agree with Aristotelian doctrine. How does Dietrich justify his interpretation? It relies on several occurrences of the term perfectio in the Aristoteles latinus. In Physics VII, Aristotle gives an account of motion which leads him to specify the definition of alteration given in the Categories. ${ }^{59}$ He points out that alteration only concerns certain types of qualities, namely sensible qualities, and not other types of qualities such as figures, dispositions, or habits. A habit, in particular, which is a certain perfectio $\left(\tau \varepsilon \lambda \varepsilon^{i} \omega \sigma i \varsigma \tau i \varsigma^{60}\right)$, cannot sustain alteration properly speaking. But while for Aristotle habits belong with accidents, Dietrich tends to give perfections a distinctive ontological status. In the De natura contrariorum, he details four (interrelated) characteristics that distinguish them from substantial and accidental forms:

1. Their inherence in substances depends on dispositions.

2. They are not composed of genus and species.

3. They do not have proper contraries.

4. They do not come to be through motion, but through direct transmutation.

First, unlike substantial and accidental forms, perfections do not inhere immediately in substances, but only through dispositions. For instance, the manifestation of light requires a subject that is already informed by some substantial form and that already possesses some determinate accidents: light will appear in a medium if and only if a number of conditions are present. Contrastingly, substantial forms inhere directly in matter, and accidents inhere directly in substances. Unlike those "constitutive" (substantial and accidental) forms, perfections do not constitute their subject and require previous qualitative dispositions such as dryness or wetness, hotness or coldness, and so on. In other words, perfections necessarily require a prior actuality in order to exist. For this reason, perfectional forms can be said to have a more accidental relation to their subjects than other types of accidental forms:

From this it follows that these forms, which I call perfections, have more accidentality with respect to a substance than accidental forms that have been described before, since they do not have a relation to a substance or

$\left.8 \mathrm{~b} 25^{-27}\right)$ and in the Metaphysics (v, 20, 1022b4-14). In paragraph 58 of the De natura contrariorum, Dietrich draws on the description presented in the Physics.

59 Aristotle, Categories 8.

6o Aristotle, Physics viI, 3, 246a13. 
inhere in it without the mediation of some accidental dispositions, which must already be present in the subject. Through these dispositions the subject is constituted in some genus of accidental being, like hot, white, transparent, pure, smooth, rarefied, and the like. ${ }^{61}$

Having formulated this property, Dietrich can now show that such forms cannot really be composed of genus and species:

\begin{abstract}
Although this genus of forms, which I call perfections, are natures extrinsic to the subject just as these forms that are principles of beings, there is no distinction in them between the form of genus and the form of species, since in the nature of perfections there is no distinction between act and potency. ${ }^{62}$
\end{abstract}

This second property follows from the fact that, before their actualization, perfectional forms do not really exist in potentia within their subject of inherence. Indeed, the actualization of perfections in a subject essentially depends on the action of an external agent. A medium adequately disposed to receive light, for example, will only receive light if an external agent actualizes it. Because a perfection need not inhere in a subject adequately disposed to receive it, a perfection cannot be said to exist in potentia in this subject. If perfections were potentially in a subject, the actualization of the required dispositions would always and automatically lead to the actualization of the corresponding perfection. Thus, a subject is not in potency toward qualitative accidents in the same sense as it is in potency toward perfections. Consequently, unlike other kinds of forms, perfections do not determine any generic potency of the subject: these forms are not the actualization of a first generic indetermination and, therefore, they are not really composed of genus and species. From a metaphysical

61 Dietrich of Freiberg, De natura contrariorum, 37, 108 $38-44$ : "Ex hoc autem huiusmodi formae, quas perfectiones dico, iam maiorem accidentalitatem habent respectu substantiae quam formae accidentales supra dictae, eo videlicet, quod non respiciunt substantiam nec ei insunt nisi mediantibus aliquibus dispositionibus accidentalibus, quas oportet praevenire in subiecto, quibus dispositionibus constituatur subiectum in genere alicuius entis secundum accidens, puta calidum, album, perspicuum, tersum, politum, rarefactum et similia."

62 Dietrich of Freiberg, De natura contrariorum, 43, 113 $87-90$ : "Quamvis autem hoc genus formarum, quas perfectiones voco, sint naturae extraneae a subiecto sicut et hae formae, quae sunt entium principia, quia tamen in natura perfectionum non distinguitur inter actum et potentiam, per consequens non reperietur in eis distinctio inter formam generis et speciei." Cf. Wallace, The Scientific Methodology, 89-9o. 
point of view, perfections are not constituted of specific differences determining a common genus, even if one can describe them in this way from a purely logical point of view. ${ }^{63}$ The same idea leads to the formulation of two corollary propositions. First, perfections cannot be organized in different species within a genus. Second, perfections are not included within genera strictly speaking. ${ }^{64}$

This last property of perfectional forms explains why they cannot have proper contraries. ${ }^{65}$ Since contraries are opposite species belonging to the same genus, one will not find true contrariety among perfections. Perfections are opposed only to their privation, not to other positive forms. The absence of positive contraries in the case of perfections finds its justification in a peculiar definition of potency (understood as a common genus) entailing the extracategorial nature of such forms. In this way, Dietrich offers a rigorous deduction to explicate the common claim that, just like substances, some accidents - be they spiritual like grace, or physical like light - do not have real contraries. Once again, we see here how Dietrich puts a common acception of "perfection" to use in his original theory of perfectional forms.

Finally, since perfections are not opposed as contrary species in the same genus, they are not acquired through motion, for motion implies a transition from one form to another, opposite form in the same genus. Rather, perfectional forms are acquired through "simple transmutation":

And as a consequence, these forms, which I have often called perfections, do not come into being by motion but by a simple transmutation, since motion only occurs from one form to another, which forms are of the same genus, as the Philosopher says in Metaphysics . $^{66}$

The term "transmutation" frequently occurs in the works of Dietrich, who includes both motion and transmutation in the subject matter of physics. ${ }^{67}$ The term transmutatio means in this precise context that the essence of perfectional forms is not successively but immediately received in a subject, because

63 Dietrich of Freiberg, De natura contrariorum, 43, 113 $3^{103-104} ; 46,114^{39}-115^{47}$.

64 Dietrich of Freiberg, De natura contrariorum, 44, 113 $3^{11-14} ; 46,114-115$.

65 Dietrich of Freiberg, De natura contrariorum, 45, 114 ${ }^{25-26: ~ " E x ~ q u o ~ u l t e r i u s ~ m a n i f e s t u m ~ e s t, ~}$ quod huiusmodi formae non habent contrarium nisi privationem."

66 Dietrich of Freiberg, De natura contrariorum, 44, 113 $3^{11-14}$ : "Unde per consequens huiusmodi formae, quas saepe dixi perfectiones, non habent fieri per motum, sed per simplicem transmutationem eo, quod motus non est nisi de forma in formam, quae sunt eiusdem generis secundum Philosophum in x Metaphysicae." See also 42, $112^{75}$.

67 Dietrich of Freiberg, De natura contrariorum, $1,83^{2-3} ; 29,103^{60} ; 57,124^{64}$. 
it is produced by the agent directly in the subject, and does not preexist in it. ${ }^{68}$ The term transmutatio is again borrowed from Aristotle's vocabulary. It is found in the Latin translation of Metaphysics x used by Dietrich (i.e., the one printed with Averroes's long commentary and commonly attributed to Michael Scot), which he quotes: "Ista enim contraria sunt ex aliis [contrariis], ex quibus sunt transmutationes". ${ }^{69}$ In this version of Aristotle's text, transmutationes translates the Greek $\mu \varepsilon \tau \alpha \beta 0 \lambda \alpha i .{ }^{70}$ Dietrich employs it to denote the instantaneous reception of perfections - instantaneity is not implied by Aristotle's original text, which uses the verb $\mu \varepsilon \tau \alpha \beta \alpha \dot{\lambda} \lambda \omega$ more broadly to refer to a change taking place between contraries. But in the case of Dietrich's perfectional forms, an "instantaneous dependence" connects the form to the external agent causing its immediate manifestation in a subject:

Thus every such perfection does and does not belong to its perfectible in a simple and indivisible way according to a simple and instantaneous dependence on its cause. ${ }^{71}$

We must point out, however, that, in the De luce, Dietrich denies that a body can instantaneously illuminate another body, because this would imply that the illuminating substance possesses an infinite power, which is impossible for natural substances. ${ }^{72}$ Nonetheless, in other places, Dietrich characterizes illumination as an instantaneous event. ${ }^{73}$ These claims appear to be contradictory but closer scrutiny will show that they are in fact compatible. Even if a body's internal power is always limited, and can only act on a given medium in time, the illumination of a medium as a process does not happen in successive moments, because light is, by nature, the perfectio of a body. Similarly, and following Aristotle's authority, Dietrich claims, already in the De luce, that

68 Dietrich of Freiberg, De natura contrariorum, $41,111^{40}$.

69 Dietrich of Freiberg, De natura contrariorum, 8, 89 $9^{50-51}$. See Averroes, In Metaphysicam $\mathrm{x}$, $263^{\mathrm{vb}} \mathrm{K}-\mathrm{L}$.

70 Aristotle, Metaphysics x, 4, 1055b16-17. Let me note that William of Moerbeke chooses permutationes instead of transmutationes (Metaphysics X, trans. William of Moerbeke, $205^{271}$ ) following James of Venice, who translated $\mu \varepsilon \tau \alpha \beta \alpha \lambda \lambda \omega$ by permutor (cf. Metaphysics I, 3, trans. James of Venice, $11^{27}-12^{28}$ ).

71 Dietrich of Freiberg, De natura contrariorum, 44, 114 22-24: “... ideo unaquaeque earum modo simplici et indivisibiliter adest et abest suo perfectibili secundum simplicem et instantaneam dependentiam a sua causa."

72 Dietrich of Freiberg, De luce, 15, 21.

73 Dietrich of Freiberg, Utrum in Deo, $298^{75}$; see also De accidentibus, 20, $81^{32-33}$, although illumination in this last passage does not seem to be taken in its physical sense. 
sensation as a power (which Dietrich also defines as a perfection) is acquired instantaneously, rather than in successive steps or through motion ("in instanti et non successive nec per motum"). ${ }^{74}$

The case of constitutive forms (both substantial and accidental) is another matter. The essence of such forms preexists in potentia in a subject, but it needs an agent to be actualized. ${ }^{75}$ There is no essential difference between a form in potency (or the potency of matter) and this same form once it has been actualized. Dietrich claims that the only difference between the form in potency and the actualized form is a difference in esse, following Albert the Great's position on the subject. ${ }^{76}$ From the nature of substantial and accidental forms, it follows that their essence already exists in potency in a subject. This explains how accidents (especially qualities) change via motion, one specific essence being replaced by another belonging to the same potential genus. The potency of generic forms allows for the presence of contrary species, which generates resistance (quaedam proportionata resistentia) against the process of information, which is why this process can only occur in time (in tempore determinato). ${ }^{77}$ Following the same line of thought, Dietrich suggests that if perfections were the only forms to exist in nature, there would be no succession in natural phenomena. ${ }^{78}$

Dietrich presents perfectional forms in a variety of ways in his works, but it is only in the De natura contrariorum that he clarifies their ontological nature. Indeed, it is in this work that Dietrich connects the characteristic properties of perfections with his theory of transcendentals. Transcendental terms (oneness, being, goodness) are extra-categorial concepts and do not add anything to the quidditative definition of beings. Such transcendental concepts are produced by intellectual activity and increase the intelligibility of objects. However, transcendentals do not refer to real things outside the intellect. ${ }^{79}$ Perfections, as we saw, are (strictly speaking) not composed of genus and species: they have a unique status, which we can better understand if we highlight their proximity with transcendentals like being and goodness. Substantial and accidental

74 Dietrich of Freiberg, De luce, 5, 12 ${ }^{12-13}$. On colors, see also De coloribus, 8, 283 $3^{118-122}$.

75 Dietrich of Freiberg, De natura contrariorum, 42, 112 ${ }^{75-79}$.

76 Dietrich of Freiberg, De natura contrariorum, 31, $105^{26-27}$. See also De corpore Christi mortuo, 3, 149 $9^{43-47}$. Cf. Albert the Great, De anima I, tr. 2, c. 7, 38 $8^{15-17}$ ("privatio in essentia est idem formae, licet secundum esse sit differens"); Physica I, tr. 3, c. 15; De caelo et mundo I, tr. 3 , c. 4.

77 Dietrich of Freiberg, De natura contrariorum, 33, 107 $7^{76-79}$.

78 Dietrich of Freiberg, De natura contrariorum, 69, 132 $2^{90-92} ; 72,133^{40-47}$.

79 On Dietrich's theory of transcendentals, see Aertsen, "Die Transzendentalienlehre"; Aertsen, Medieval Philosophy, 316-330; Goris, "Dietrich von Freiberg." 
forms are principles for actual beings, as they provide a formal act sustaining the existence of created beings. ${ }^{80}$ But perfectional forms are different: they require the prior existence of actual beings. Perfections are real entities, but not autonomous beings. Perfections only bring a supplementary degree or mode of goodness to what already exists, since they are not constitutive forms:

But perfection carries a certain degree or mode of goodness added to some act qua act, and because of this it is understood as a complement of an act qua act. ${ }^{81}$

Focusing on the ontology of forms, the De natura contrariorum offers a categorial analysis of perfections. This analysis allows Dietrich to compare them with other types of forms in minute detail and to explain their function in the sensible world. In addition, bringing forth the deeper metaphysical structure of perfectional forms retrospectively justifies their modal and physical properties, which Dietrich had formulated in earlier works.

\section{The Influence of Dietrich's Theory}

The multiplicity of perspectives through which perfections are analyzed gives a good illustration of the protean nature of the concept. But this should not detract from its central position in Dietrich's system. While his theological question on God's intellect describes the modal properties of perfections in order to understand the structure of the intellect, the De luce connects perfectional forms with the problem of substantial composition and the concept of part. Finally, after establishing that perfections have no contrary forms, the De natura contrariorum deduces their ontological properties and justifies their cosmological role. This shows how the adaptability of perfectional form allows Dietrich to use the concept in a wide variety of arguments and yet, despite its extensive application, he never produces an explicit, unified account of the concept. This being said, it would be difficult to deny any connection between these different applications. As William A. Wallace has shown in his monograph on Dietrich's scientific methodology, the Dominican philosopher's optical studies are tightly intertwined with the metaphysical and logical reflections

80 Dietrich of Freiberg, De natura contrariorum, 30, $104^{2-3}$.

81 Dietrich of Freiberg, De natura contrariorum, 37, 10957-59: "Perfectio autem importat aliquem gradum sive modum bonitatis superadditum alicui actui, inquantum est actus, et eo modo intelligitur esse complementum actus inquantum actus." 
he develops in his philosophical writings. ${ }^{82}$ The case of perfectional forms is in perfect agreement with this view. Light is an important analogy for Dietrich's analysis of the emanative structure of the intelligible world, of which his theory of the intellect constitutes a central piece. The distinct definitions of perfections closely parallel the main claims of his philosophical system concerning the nature of accidents, transcendentals, and the intellect. Thus, the notion of forma perfectionalis ties in with Dietrich's overall project: to develop an emanative metaphysics drawing on an analogy with light within an Aristotelian conceptual framework.

Dietrich's views certainly influenced the German Dominican school, although the exact scope of that influence is hard to appreciate. Despite his disagreements with Dietrich on several topics, Nicholas of Strasbourg seems to rely to a certain extent on Dietrich's analyses in the third part of his Summa philosophiae (ca. 1315-1320) which, as its title (De formis) indicates, is devoted to the study of forms. ${ }^{83}$ The similarity may be most strongly noticeable in Nicholas's definition of intentional forms, i.e., forms present in a medium and perceivable by the senses. He lists eight conditions - although he initially announces only four - for this type of forms to obtain:

1. No contrariety or opposition is to be found between them.

2. They are produced instantaneously.

3. They do not admit of more or less.

4. They inhere more loosely into their subject than other forms.

5. They do not denominate their subject as real forms do.

6. They produce sensations when affecting the senses (unlike real forms).

7. The generated thing assimilates its generator much more than in the case of real forms.

8. Two intentional forms of contrary species (e.g. black and white) or two whitenesses can be present in the same subject. ${ }^{84}$

82 Wallace, The Scientific Methodology.

83 On the relation between Nicholas and Dietrich, see Sturlese, "Eckhart," and Imbach, "Metaphysik." See also Pellegrino, "La Summa."

84 Nicholas of Strasbourg, Summa philosophiae III, Città del Vaticano, Biblioteca Apostolica Vaticana, Ms Vat. lat. 3091, $261^{\mathrm{vb}}-262^{\text {ra: }}$ "Quattuor sunt condiciones formarum intentionalium. Prima est quod ipsae non habent aliquam contrarietatem vel oppositionem ad invicem. Secunda est quod ipsae producuntur in instanti. Tertia est quod ipsae non recipiunt magis et minus. Quarta est quod sunt debilioris inhaerentiae vel inhaesionis quam quaecumque aliae formae. Solum enim inhaerent subiecto ad praesentiam producentis eas et post ipsius absentiam nequaquam amplius adhaerent subiecto, ut ad sensum apparet de forma in speculo. Quinta condicio est quia ut plerumque subiectum suum non denominant, omnes autem reales formae subiecta sua denominant. Sexta condicio 
Nicholas claims that the "three" other properties (2 to 4, presumably) can be deduced from the first one. ${ }^{85}$ This way to show that the properties of intentional forms are grounded on the lack of contraries closely resembles Dietrich's approach in the De natura contrariorum. For instance, the lack of contrariety (1) explains that intentional forms are produced instantaneously (2), do not admit of degrees (3), and have a more indirect inherence relation to their subject (4), just like Dietrich's perfectional forms. The seventh property echoes Dietrich's description of perfectional forms as a transmission of the agent's own nature into a subject.

But there the resemblance ends. Nicholas's objective is different from Dietrich's, since Nicholas analyzes intentional forms - a type of forms he characterizes as non-real. As we saw in Dietrich's works, perfectional forms helped conceptualize the status of sensations through an analogy with light. In some sense, the account of intentional forms in the Summa philosophiae merges the application of perfectional form to sensation with the light analogy: intentional forms are present in a medium, like light is, and they are received by the senses to produce sensations. But, according to Nicholas, intentional and real forms differ in ontological status. This explains why the former have particular properties (most of all conditions 5 and 8) which do not come up in Dietrich's account of perfections. In Nicholas's view, intentional forms do not denominate their subject (condition 5 ) because they only exist in it potentially. But physical light does denominate its subject - we call air in which light is present "illuminated air" ("sicut lumen denominat aerem illuminatum"86) - because it is a real form, actually present in its subject rather than only potentially. For the same reason, intentional forms belonging to opposite species can exist in the same subject because they are only potentially present in it. ${ }^{87}$ Assuming

est quod formae intentionales positae supra sensum faciunt sensum, quod non faciunt reales. Septima condicio est quod in generatione istarum formarum genitum multo plus assimilatur generanti quam in quacumque generatione vel eductione formae realis. Additur tamen et octava condicio ... quod duae formae intentionales contrariae, ut species albi et species nigri et etiam duae formae intentionales duarum albedinum possint esse simul in eodem subiecto, ut in eadem parte punctali aeris."

85 Nicholas of Strasbourg, Summa philosophiae III, 262 $2^{\text {ra: }}$ "Et per omnes istas condiciones differunt formae intentionales a realibus. Et ex declaratione primae condicionis patet declaratio omium aliarum trium condicionum."

86 Nicholas of Strasbourg, Summa philosophiae III, $263^{\text {va }}$.

87 Nicholas of Strasbourg, Summa philosophiae III, 262 $2^{\text {va: }}$ "Dicamus quod quamvis contraria non possint esse simul actu, tamen bene sunt simul potentia, sicut unum et idem bene simul est potentia album et nigrum, et quamvis non possint esse simul secundum esse completum, tamen bene sunt simul secundum esse incompletum, sicut quamvis album et nigrum non possint esse simul secundum esse completum quod habent in se ipsis ut 
that Nicholas did have Dietrich's theory of perfectional forms in mind when he developed his own concept of intentional form, here is a possible reason why he may have chosen to stray from Dietrich's path: according to Nicholas, intentional forms, since they exist only in potency, are imperfect. ${ }^{88}$ Nicholas also accounts for the fundamental property of intentional forms in his own way: they lack contrariety because light - which bears intentional forms (e.g., colors) - comes from the heavens, in which contrariety does not exist. ${ }^{89}$

The similarities between Nicholas's analysis of forms and Dietrich's can therefore not be regarded as evidence of a direct influence of the latter on the former. Not only does Nicholas make no mention of Dietrich (a fact which, however, is not significant on its own since Nicholas sometimes does use Dietrich's doctrines without quoting them explicitly ${ }^{90}$ ) or of the syntagm "perfectional forms", but furthermore his very project appears to be altogether distinct from Dietrich's. Despite these differences, the way Nicholas intends to deduce several characteristics of intentional forms from a more limited set of their properties (in this case, from the fact that they do not have contraries) closely matches Dietrich's method in his theory of forms, and makes use of the very same criteria. The fact that Nicholas's reasoning leads him to analyze the nature of light together with sensory perceptions also echoes Dietrich's analyses. It is as if Nicholas borrows several elements of Dietrich's theory of perfectional forms but integrates them into his own philosophical project. Taking all these elements into account, Dietrich's influence on Nicholas regarding his theory of forms must unfortunately remain a mere conjecture at present.

Dietrich's influence on Berthold of Moosburg (d. 1361) is, however, indisputable. We know that Berthold developed the Neoplatonist inspirations of his Dominican predecessors, choosing to adapt the theoretical content of Proclus's Elementatio theologica to suit a Christian perspective without discarding the

sunt extrema, sunt tamen bene simul secundum esse incompletum quod habent in suo medio."

88 Nicholas of Strasbourg, Summa philosophiae III, 262 va: "Volumus autem dicere quod esse formarum intentionalium sit quidam motus vel quod ipsae moveantur vel producantur per motum. Sed volumus dicere quod non dicunt perfectam actualitatem sed incompletam et quod non habent esse permanens et fixum, sed eorum esse se habet per modum cuiusdam fieri, sicut declaratum est; et in hoc conveniunt cum motu."

89 Nicholas of Strasbourg, Summa philosophiae III, $262^{\text {rb: }}$ "Colores non sunt in medio nec agunt in ipsum vel oculum nisi per actum luminis. Lumen autem est qualitas non habens contrarium, sicut statim infra patebit, quia lux est quaedam qualitas consequens formam substantialem corporis caelestis, et cum in caelo nulla sit contrarietas nec ista qualitas habebit aliquam contrarietatem ..."

See Sturlese, "Einleitung," XI. 
intermediary beings (henads and intellectual hypostases) located, in Proclus's system, between God and the sensible universe. ${ }^{91}$ As is well known, Berthold's thought was deeply influenced by many aspects of Dietrich's system, in particular his theory of essential causation and his theory of the intellect. ${ }^{92}$

In his commentary on Proclus's Elementatio theologica, Berthold explicitly refers to Dietrich's theory of formae perfectionales. His quotations of Dietrich's writings bear witness to the importance of this theory for an emanatist account of the universe. For instance, Berthold cites major passages of the De natura contrariorum and the question Utrum in Deo when commenting on Proposition 79 of the Elements ("Omne quod fit, ex duplici fit potentia"). ${ }^{93}$ Everything that comes into being requires a double potency, since it requires an agent having the (active) potency to generate it and, correspondingly, the possibility to come into being (passive potency). In order to explain how every created being comes to actual existence from a double potency, Berthold makes use of Dietrich's distinction between constitutive and perfectional forms. This allows him to justify how some entities containing so to speak no potentiality are still in potency to something else. ${ }^{94}$

In his commentary, Berthold also quotes passages of the De natura contrariorum (paragraph 44) which discuss how perfectional forms suppose a simple and instantaneous dependence on their sources. ${ }^{95}$ The instantaneity of perfectional forms is, here, a crucial point. Because Berthold is willing to ground a Neoplatonist account of the universe, his theory of the causal relations between the different layers of the created universe must fit with the properties of emanation. While the material changes occurring in the natural realm take some time, because of matter and the presence of contrary qualities in it, there cannot be any time delay between a cause and its effect when it comes to the vertical relation between a created being and its causes. For instance, the creation of an intellect (e.g., the human one) is not a temporal process, because an intellect does not come to be through motion. As we have seen, the concept of perfectional forms as Dietrich designed it refers to those forms having a direct and essential relation vis-à-vis their cause. For this rea-

91 For recent comprehensive studies, see King, Supersapientia, and Ludueña, La recepción. On Berthold's Neoplatonist influences, see also Mojsisch, "Die Theorie des Intellekts"; King, "Berthold of Moosburg"; King, "Eriugenism." About Dietrich's influence on Berthold, see Führer and Gersh, "Dietrich of Freiberg”; De Libera, La mystique rhénane, 317-442.

93 Berthold of Moosburg, Expositio, Prop. 79, esp. 95-97.

94 Berthold of Moosburg, Expositio, Prop. 79, 95-96.

95 Berthold of Moosburg, Expositio, Prop. 79, 97 $212-217$, quoting Dietrich of Freiberg, De natura contrariorum, 44, $113^{11-14}$. 
son, perfectional forms are instantaneously produced by their cause. We can thus easily understand why this concept was interesting from Berthold's perspective.

Berthold also employs Dietrich's theory in his own doctrine of light, when commenting on Proposition 143 of Proclus's Elementatio ("Omnia deteriora praesentia deorum subsistunt. Et si idoneum sit participans, omne quidem quod alienum a divino lumine fit, illustratur autem omne subito a diis"). To account for the term "subito", Berthold looks again to the instantaneous character of light. Since in this context the word "light" denotes a spiritual mode of action, the instantaneity of divine illumination cast upon lower beings must be explained in cognitive terms: lower souls - even those remote from God are always immediately illuminated by the divine light. ${ }^{96}$ Berthold's interpretation of this proposition relies on a complex theory of light according to which light diffusion models the ontological emanation of created multiplicity, following a famous Neoplatonist analogy. ${ }^{97}$ Berthold distinguishes three types of light - supersubstantial (i.e., divine), intellectual, and corporeal - in order to explain how the sensible universe emanates from the divine realm. While corporeal light is light as we know it on the sensible plane, the concept "intellectual light" denotes the process of understanding proper to intellectual natures. The expression "supersubstantial light" refers to God as the source of all perfections in nature and in the realm of intelligible beings. As such, supersubstantial light is the ultimate source of intellectual and corporeal lights.

This theory explains the decisive importance of the image of light in Berthold's doctrine: it supports his analysis of creation as an emanative process, that is, as an ontological flux in which every created being is continuously dependent on God's irradiating action. Corporeal light, despite its remoteness from the highest spheres of reality, still retains something of God's supersubstantial action..$^{98}$ Remarkably, Berthold here again uses paragraph 44 of Dietrich's De natura contrariorum to draw on the instantaneous dependence implied by the notion of formae perfectionales, just like in his commentary on Proposition 79. Like supersubstantial light in the divine realm and corporeal light in the sensible world, the act of understanding is an instantaneous

\footnotetext{
96 Berthold of Moosburg, Expositio, Prop. 143, $72^{430-434}$.

97 See Faës de Mottoni, "Il problema," and De Libera, La mystique rhénane, 410-423.

98 Berthold of Moosburg, Expositio, Prop. 143, 69 314-318: "Unde, sicut lux corporalis est formaliter et causaliter pulchritudo omnium visibilium, sic lux divina est formalis causa pulchritudinis cuiuscumque formae: omnis enim forma, cum sit effectus primae lucis divinae sive sit divina secundum essentiam sive secundum causam, participat similitudinem primae lucis."
} 
process, which ensures the immediate and constant noetic dependence of created entities on higher orders of being (intellectual hypostases and, ultimately, God). ${ }^{99}$ Here again, Berthold employs Dietrich's characterization of perfectional forms to prove specific aspects of his cosmology. Since intellectual habits and light are defined as perfectional forms, what is true of corporeal light can be applied mutatis mutandis to the properties of intellection. Given that intellection plays an important role in the emanative framework of Berthold's Neoplatonist metaphysics, and given that even God's action may be described in terms of (supersubstantial) light, the properties of light acquire a metaphysical dimension. From this perspective, Berthold uses perfectional forms as a conceptual resource allowing him to base statements about the structure of creation on the phenomenal properties of light.

This extension of Dietrich's theory can still be seen elsewhere. Following Dietrich's classification of forms, Berthold mentions perfectional forms whenever he details the many senses of the terms "actus" and "potentia". ${ }^{100}$ But while Berthold makes use of Dietrich's theory to describe the mode of action proper to divine and intellectual beings, he also uses it in a broader sense, sometimes going farther than Dietrich did. For example, in his commentary on Proposition 44, Berthold seems to totally identify perfectional forms with operations, a claim Dietrich does not make. According to Berthold, since every being tends toward its proper operation, through which it achieves its end and ontological completion ("propria operatio habet rationem boni et finis"101), operations as such amount to perfectional forms. ${ }^{102}$ This applies to natural beings as well as to supernatural ones, even if in the latter case substance, potency, and operation are not really distinct. ${ }^{103}$ In other words, whereas Dietrich mostly analyzed sensory and intellectual operations in terms of perfectional forms, Berthold is inclined to extend this notion to operations in general.

Dietrich's main interest in the theory of perfectional forms was to provide a suitable explanation for the relational character of luminous phenomena and cognitive activities. Berthold has a more focused interest in perfectional

\footnotetext{
99 Berthold of Moosburg, Expositio, Prop. 143, $73^{462-470}$.

100 For instance Prop. 77, $76^{77-81}$, and $76^{98-102}$.

101 Berthold of Moosburg, Expositio, Prop. 44, $74^{40}$.

102 Berthold of Moosburg, Expositio, Prop. 44, 74 37-38, 61-64: "Quantum ad secundum, quid scilicet sit operatio, sciendum. Ubi primum occurrit ipsam esse actum, cum sit perfectio et complementum operantis ... Secundus [sc. modus formarum] autem est de genere actus secundi, qui non est nisi complementum rei et eius perfectio, ut dictum est. Manifestum est autem propriam rei operationem sive in naturalibus sive in supernaturalibus esse de genere actus secundi."

103 Berthold of Moosburg, Expositio, Prop. 44, 75 $72-75$.
} 
forms: he singles out relevant aspects of Dietrich's doctrine to integrate into the psychological and cosmological views which nourish his metaphysical system. Perfectional forms work to justify the non-temporal character of higher cognitive processes. For Proclus, the peculiar temporality of these processes is cosmologically significant, allowing them to be fitting parts of an eternally emanated universe. Berthold naturally rejects the eternity of the world, but perfectional forms still successfully explain the instantaneous ontological dependence of created beings on higher spiritual principles in a hierarchical universe.

\section{Conclusion}

To conclude, whereas Dietrich's concern was to develop an ontological account consistent with his views of optics, Berthold extends the scope of Dietrich's analyses beyond the philosophy of nature. Bringing together somewhat disparate applications of Dietrich's perfectional form into a more comprehensive concept of perfection, Berthold grounds his Neoplatonist account of creation on a literal interpretation of light as its model. He applies the essential properties of physical light (instantaneous character; essential dependence on the source; absence of any positive contrary), characterized as a perfectional form, to the analysis of divine creation which, mutatis mutandis, presents the same properties and, thus, can be adequately described as light. Used in the analysis of the notion of perfection, light is no longer a simple metaphor, but rather a dynamic reality whose intellectual, cosmological, and physical properties express distinct levels of ontological emanation. This shows the role played by Dietrich's theory of perfectional forms in the intellectual tradition of the German Dominicans: resulting from Dietrich's intent to find rigorous philosophical foundations for his scientific views, perfectional forms went on to conceptually reshape formal causality in the German Dominican school.

\section{References}

\section{Authors before ca. 1500}

Albert the Great, De anima, ed. C. Stroick. Opera omnia 7/1 (Münster, 1968).

Albert the Great, De caelo et mundo, ed. P. Hossfeld. Opera omnia 5/1 (Münster, 1971). Albert the Great, De homine, eds. H. Anzulewicz and J. R. Söder. Opera omnia 27/2 (Münster, 2008).

Albert the Great, Physica. Libri I-IV, ed. P. Hossfeld. Opera omnia 4/1 (Münster, 1987). 
Albert the Great, Super Dionysium De divinis nominibus, ed. P. Simon. Opera omnia 37/1 (Münster, 1972).

Aristotle, Metaphysica, Lib. I-IV.4. Translatio Iacobi sive 'Vetustissima' cum Scholiis et Translatio Composita sive 'Vetus', ed. G. Vuillemin-Diem. Aristoteles latinus 25/1-1a (Brussels, 1970).

Aristotle, Metaphysica, Lib. I-XIV. Recensio et Translatio Guillelmi de Moerbeka, ed. G. Vuillemin-Diem. Aristoteles latinus 25/3.2 (Leiden, 1995).

Averroes, In Metaphysicam. Aristotelis opera cum Averrois commentariis 8 (Venice, 1562; repr. Frankfurt am Main, 1962).

Avicenna, Liber de anima seu sextus de naturalibus, ed. S. Van Riet. 2 vols. (Leuven, Leiden, 1972).

Berthold of Moosburg, Expositio super Elementationem theologicam Procli, Propositiones 35-65, ed. A. Sannino (Hamburg, 2001).

Berthold of Moosburg, Expositio super Elementationem theologicam Procli, Propositiones 66-107, ed. I. Zavattero (Hamburg, 2003).

Berthold of Moosburg, Expositio super Elementationem theologicam Procli, Propositiones 136-159, ed. F. Retucci (Hamburg, 2007).

Dietrich of Freiberg, Quaestio utrum in Deo sit aliqua vis cognitiva inferior intellectu, ed. M. R. Pagnoni-Sturlese. Opera omnia 3 (Hamburg, 1983), 283-315.

Dietrich of Freiberg, Tractatus de accidentibus, ed. M. R. Pagnoni-Sturlese. Opera omnia 3 (Hamburg, 1983), 47-9o.

Dietrich of Freiberg, Tractatus de animatione caeli, ed. L. Sturlese. Opera omnia 3 (Hamburg, 1983), 1-46.

Dietrich of Freiberg, Tractatus de coloribus, ed. R. Rehn. Opera omnia 4 (Hamburg, 1985), 269-288.

Dietrich of Freiberg, Tractatus de corpore Christi mortuo, ed. M. R. Pagnoni-Sturlese. Opera omnia 2 (Hamburg, 1980), 137-150.

Dietrich of Freiberg, Tractatus de intellectu et intelligibili, ed. B. Mojsisch. Opera omnia 1 (Hamburg, 1975), 125-216.

Dietrich of Freiberg, Tractatus de luce et eius origine, ed. R. Rehn. Opera omnia 4 (Hamburg, 1985), 1-24.

Dietrich of Freiberg, Tractatus de natura contrariorum, ed. R. Imbach. Opera omnia 2 (Hamburg, 1980), 69-135.

Dietrich of Freiberg, Tractatus de quiditatibus entium, eds. R. Imbach and J.-D. Cavigioli. Opera omnia 3 (Hamburg, 1983), 91-118.

Dietrich of Freiberg, Tractatus de visione beatifica, ed. B. Mojsisch. Opera omnia 1 (Hamburg, 1975), 1-124.

Nicholas of Strasbourg, Summa. Liber 2, tractatus 1-2, ed. G. Pellegrino (Hamburg, 2009).

Nicholas of Strasbourg, Summa philosophiae, Città del Vaticano, Biblioteca Apostolica Vaticana, Ms Vat. lat. 3 og1. 


\section{Authors after ca. 1500}

Aertsen, J. A. "Die Transzendentalienlehre bei Dietrich von Freiberg." In Dietrich von Freiberg. Neue Perspektiven seiner Philosophie, Theologie und Naturwissenschaft, eds. K. H. Kandler, B. Mojsisch and F. B. Stammkötter (Amsterdam, 1999), 23-47.

Aertsen, J. A. Medieval Philosophy as Transcendental Thought. From Philip the Chancellor (ca. 1225) to Francisco Suárez (Leiden, 2012).

Biard, J., D. Calma and R. Imbach, eds. Recherches sur Dietrich de Freiberg (Turnhout, 2009).

Boer, S. W. de. The Science of the Soul. The Commentary Tradition on Aristotle's De anima, c. 1260-c. 136o (Leuven, 2013).

De Libera, A. La mystique rhénane. D'Albert le Grand à Maître Eckhart (Paris, 1994).

De Libera, A. Métaphysique et noétique: Albert le Grand (Paris, 2005).

Decaix, V. "Structure et fonction de la causalité essentielle chez Dietrich de Freiberg." Chôra 12 (2014), 171-188.

Dijksterhuis, E. J. De mechanisering van het wereldbeeld (Amsterdam, 1950).

Erismann, C. "Causa essentialis. De la cause comme principe dans la métaphysique de Jean Scot Erigène." Quaestio 2 (2002), 187-216.

Faës de Mottoni, B. "Il problema della luce nel Commento di Bertoldo di Moosburg all'Elementatio theologica di Proclo. Edizione delle proposizione riguardante il tempo e l'eternità." Studi medievali 16 (1975), 325-352.

Faës de Mottoni, B. "La distinzione tra causa agente e causa motrice nella Summa de Summo Bono di Ulrico di Strasburgo." Studi medievali 20 (1979), 313-355.

Flasch, K. Dietrich von Freiberg. Philosophie, Theologie, Naturforschung um 1300 (Frankfurt am Main, 2007).

Führer, M., and S. Gersh. "Dietrich of Freiberg and Berthold of Moosburg." In Interpreting Proclus From Antiquity to the Renaissance, ed. S. Gersh (Cambridge, 2014), 299-317.

Goris, W. "Dietrich von Freiberg und Meister Eckhart über das Gute." In Dietrich von Freiberg. Neue Perspektiven seiner Philosophie, Theologie und Naturwissenschaft, eds. K. H. Kandler, B. Mojsisch and F. B. Stammkötter (Amsterdam, 1999), 169-188.

Hasse, D. N. "The Early Albertus Magnus and his Arabic Sources on the Theory of the Soul." Vivarium 46 (2008), 232-252.

Imbach, I. "Metaphysik, Theologie und Politik. Zur Diskussion zwischen Nikolaus von Straßburg und Dietrich von Freiberg über die Abtrennbarkeit der Akzidentien." Theologie und Philosophie 61 (1986), 359-395.

Kandler, K. H. Dietrich von Freiberg. Philosoph, Theologe, Naturforscher (Freiberg, 2009).

Kandler, K. H., B. Mojsisch and F. B. Stammkötter, eds. Dietrich von Freiberg. Neue Perspektiven seiner Philosophie, Theologie und Naturwissenschaft (Amsterdam, 1999).

King, E. "Berthold of Moosburg on Intellect and the One of the Soul." Dionysius 36 (2018), 184-199. 
King, E. "Eriugenism in Berthold of Moosburg's Expositio super Elementationem theologicam Procli." In Reading Proclus and the Book of Causes, vol. 1, ed. D. Calma (Leiden, 2019), 394-437.

King, E. Supersapientia: Berthold of Moosburg and the Divine Science of the Platonists (Leiden, 2021).

König-Pralong, C. "Le Traité des accidents de Dietrich de Freiberg. Stratégies exégétiques pour une reconduction de l' accidentel au par soi." In Recherches sur Dietrich de Freiberg, eds. J. Biard, D. Calma and R. Imbach (Turnhout, 2009), 107-129.

Lenzi, M. Anima, forma e sostanza: filosofia e teologia nel dibattito antropologico del XIII secolo (Spoleto, 2011).

Ludueña, E. La recepción de Eriúgena en Bertoldo de Moosburg: Un aporte sobre la Escuela de Colonia (Saarbrücken, 2013).

Maurer, A. A. "The De Quiditatibus Entium of Dietrich of Freiberg and its Criticism of Thomistic Metaphysics." Mediaeval Studies 18 (1956), 173-203.

McPike, D. R. Thomas Aquinas on the Separability of Accidents and Dietrich of Freiberg's Critique. Dissertation (University of Ottawa, 2015).

Mojsisch, B. "Causa essentialis bei Dietrich von Freiberg und Meister Eckhart." In Von Meister Dietrich zu Meister Eckhart, ed. K. Flasch (Hamburg, 1980), 106-114.

Mojsisch, B. "Die Theorie des Bewußtseins (ens conceptionale) bei Dietrich von Freiberg. Aristoteles-Rezeption und Aristoteles-Transformation im 13. Jhdt." In Per perscrutationem philosophicam. Neue Perspektiven der mittelalterlichen Forschung. Loris Sturlese zum 6o. Geburtstag gewidmet, eds. A. Beccarisi, R. Imbach and P. Porro (Hamburg, 2008), 142-155.

Mojsisch, B. "Die Theorie des Intellekts bei Berthold von Moosburg. Zur Proklosrezeption im Mittelalter." In Selbst - Singularität - Subjektivität. Vom Neuplatonismus zum Deutschen Idealismus, eds. T. Kobusch, B. Mojsisch and O. F. Summerell (Amsterdam, 2002), 175-184.

Mojsisch, B. "Sein als Bewußt-Sein. Die Bedeutung des ens conceptionale bei Dietrich von Freiberg." In Von Meister Dietrich zu Meister Eckhart, ed. K. Flasch (Hamburg, 1980), 95-105.

Mojsisch, B. "The Theory of Intellectual Construction in Theodoric of Freiberg." Bochumer Philosophisches Jahrbuch für Antike und Mittelalter 2 (1997), 69-78.

Park, K. "Albert's Influence on Late Medieval Psychology." In Albertus Magnus and the Sciences. Commemorative Essays, ed. J. A. Weisheipl (Toronto, 1981), 501-535.

Pellegrino, G. "La Summa di Nicola di Strasburgo (1315-1320): 'Compilatio rudis ac puerilis' o 'novus libellus'?” In Per perscrutationem philosophicam. Neue Perspektiven der mittelalterlichen Forschung. Loris Sturlese zum 6o. Geburtstag gewidmet, eds. A. Beccarisi, R. Imbach and P. Porro (Hamburg, 2008), 204-215.

Rosemann, P. W. Omne agens agit sibi simile. A "Repetition" of Scholastic Metaphysics (Leuven, 1996). 
Roudaut, S. "The Definition of Contrariety and the Classification of Forms in Dietrich of Freiberg's De natura contrariorum." Recherches de Théologie et de Philosophie médiévales 87 (2020), 27-58.

Sturlese, L. "Eckhart, Teodorico e Picardi nella Summa philosophiae di Nicola di Strasburgo." Giornale critico della filosofia italiana 61 (1982), 183-206.

Sturlese, L. "Einleitung." In Nicholas of Strasbourg, Summa. Liber 2, tractatus 1-2, ed. G. Pellegrino (Hamburg, 2009), VII-XXI.

Sturlese, L. "Il De animatione caeli di Teodorico di Freiberg." In Xenia medii aevi historiam illustrantia oblata Thomae Kaeppeli O.P., eds. R. Creytens and P. Künzle (Rome, 1978), 175-247.

Suarez-Nani, T. Les anges et la philosophie. Subjectivité et fonction cosmologique des substances séparées au XIII ${ }^{e}$ siècle (Paris, 2002).

Trego, K. "La métaphysique de la cause. Note sur la cause agente, et la (re-)naissance de la cause efficiente," Chôra 12 (2014), 145-169.

Tsopurashvili, T. "Die causa essentialis-Theorie als Grundlage der Sprachtheorie? Sprachmodelle des Dietrich von Freiberg und Meister Eckharts." Bochumer Philosophisches Jahrbuch für Antike und Mittelalter 18 (2015), 108-129.

Vasiliu, A. Du diaphane. Image, milieu, lumière dans la pensée antique et médiévale (Paris, 1997).

Wallace, W. A. The Scientific Methodology of Theodoric of Freiberg: A Case Study of the Relationship between Science and Philosophy (Fribourg, 1959). 